\title{
African Americans respond to stigmatization: the meanings and salience of confronting, deflecting conflict, educating the ignorant and 'managing the self'
}

\section{Citation}

Fleming, Crystal, Michèle Lamont, and Jessica Welburn. 2012. African Americans respond to stigmatization: the meanings and salience of confronting, deflecting conflict, educating the ignorant and 'managing the self.' Ethnic and Racial Studies 35, no. 3: 400-417.

\section{Published Version}

doi:10.1080/01419870.2011.589527

\section{Permanent link}

http://nrs.harvard.edu/urn-3:HUL.InstRepos:10482582

\section{Terms of Use}

This article was downloaded from Harvard University's DASH repository, and is made available under the terms and conditions applicable to Open Access Policy Articles, as set forth at http:// nrs.harvard.edu/urn-3:HUL.InstRepos:dash.current.terms-of-use\#OAP

\section{Share Your Story}

The Harvard community has made this article openly available.

Please share how this access benefits you. Submit a story.

\section{Accessibility}




\title{
Responding to Stigmatization and Gaining Recognition: Evidence from Middle Class and Working Class African-Americans \\ Crystal Fleming
}

Michèle Lamont

And

Jessica Welburn

\begin{abstract}
Drawing on interviews with 150 randomly sampled African-Americans, we analyze how members of a stigmatized group understand their experience of stigmatization and assess appropriate responses when asked about best approach to deal with stigmatization and about responses to specific incidents. Combining in-depth interviews with a systematic coding of the data, we make original contributions to the previous literature by identifying the relative salience of modalities and tools for responding. We also examine closely through qualitative data the two most salient modalities of response, “confronting” and “deflating” conflict, the most salient tools, teaching outgroup members about African-Americans, and “the management of the self,” a rationale for deflating conflict that is largely overlooked in previous studies. We find that “confronting” is the more popular modality for responding to stigmatization among African-Americans.
\end{abstract}

KEYWORDS African-Americans, stigma, responses, identity, boundaries, anti-racism 
Goffman (1963) identified the myriad ways people with “discrediting” attributes manage their spoiled identities. While sociologists and social psychologists have analyzed how members of stigmatized ethno-racial groups manage their stigma, we have yet to develop a systematic survey of the range of strategies that people use, of their relative salience, and of the conditions that elicit some strategies over others. Potential strategies include explicitly confronting stereotypes and prejudices; avoiding conflict by molding one's self-presentation so as to prevent discomfort in others; offering concrete proof of equality (e.g. through competence or the display of expensive consumer goods); and asserting cultural membership, feelings of self-worth and even superiority over dominant groups. This paper draws on interviews with 150 randomly sampled middle and working class African-Americans living in the New York suburbs to inform our knowledge of responses to stigmatization. This is crucial given the United States' continued history of racial discrimination. While some celebrated America's color-blindness and post-racialism after the Obama elections, as survey data and our interviews suggest, African-Americans continue to perceive pervasive racism, and to anticipate and respond to stereotyping and discrimination. This emotional work is a crucial part of their daily experience and has a direct impact on racial disparities in health and well-being (Williams, Neighbors and Jackson 2003; Lamont 2009).

Everyday responses to stigmatization are defined as the rhetorical and strategic tools deployed by individual members of stigmatized groups in reaction to perceived stigmatization (including exclusion, misrecognition, racism, and discrimination). Psychologists have given consideration to the intra-psychological mechanisms through which members of stigmatized groups cope with perceived stigma (e.g. Crocker, Major 
and Steele, 1998; Clark et al., 1999; Pinel, 1999, Oyserman and Swim 2001), for a review of the literature on stigma, see Link and Phelan, 2000). They do so by improving subjective well-being through goal attainment and self-enhancement (Oyserman, Coon, and Kemelmeier, 2002). Because social psychologists draw on experiments, they bypass a wide range of responses to stigma that inductive analysis reveals. And in contrast to our approach, they do not put meaning-making at the front and center of their analysis in their concern for in-group and out-group biases (Tajfel and Turner, 1979).

Social scientists have documented several aspects of African-American antiracism: ${ }^{\mathrm{i}}$ oppositional consciousness and anti-racists social movements (e.g. McAdam, 1988); everyday struggles and talk (Frederick, 2003; Harris-Lacewell, 2004); and responses to racism—e.g., how middle class blacks find allies, downplay differences and denounce abuse (most importantly, Feagin (1991), Feagin and Sikes (1994), Anderson (1999), and Lacy (2007)). Moreover, research that does not concern everyday anti-racism- for instance, studies of why and how African-Americans invest in education (Warikoo and Carter, 2009), engage in high culture (Banks, 2009), understand mobility (Young, 2004), conceptualize racial differences (Morning, 2009) and demarcate themselves from "ghetto blacks” (Pattillo-McCoy, 1999) informs our understanding of responses to stigmatization. In addition, Lamont and her coauthors have studied how stigmatized groups go about gaining recognition, considering 1) how elite African-Americans use religion and competence (Lamont and Fleming, 2005); 2) how black marketing specialists use consumption (Lamont and Molnár, 2002); 3) how minority workers in France and the United States use a wider range of types of evidence 
of racial equality than white workers (Lamont, 2000; Lamont and Aksartova, 2002); and 4) how North-African blue collar workers in France multiply strategies to establish their similarity and cultural compatibility with the French (Lamont, Morning and Mooney, 2002). We build on these studies to broaden our theoretical and empirical understanding of responses to stigma.

Our empirical contribution consists in providing detailed knowledge about responses to stigmatization based on a systematically collected and coded data set of interviews with African-Americans. This data makes it possible to identify the range and relative salience of responses to stigmatization found in this population. We also focus on "best approaches" for dealing with racism, as well as on more subtle responses (i.e., "managing the self”) that have not been considered in previous research. ${ }^{\mathrm{ii}}$

After describing methods, we open with a description of African-Americans experiencing stigma. Then we provide a snapshot of modalities and tools that AfricanAmericans say they mobilize to respond to racism and identify their relative salience. We examine closely the two most salient modalities of response, “confronting” and "deflating" conflict, and show that the former is more popular than the latter. Then, we examine the most salient tools, teaching out-group members about African-Americans and "the management of the self," a rationale for deflecting conflict that has been by and large overlooked in the literature.

\section{1) Methods}


We draw on open-ended two-hour interviews with 150 working and middle class men and women living in the New York suburbs, in towns such as Patterson, Irvington, South Plainfield and South Orange in New Jersey. ${ }^{\text {iii }}$ The New York metropolitan area presents a full spectrum of social classes for both majority and minority groups. ${ }^{\text {iv }}$ Our sample is composed of only native-born individuals and individuals who have been residents of the area for at least five years. It excludes first and second generation children of immigrants. A table of respondent characteristics (by occupation, age, gender, and class) is available online (at www.identifying information), as is information about their recruitment.

We conducted interviews with a relatively large number of respondents (by the standards of qualitative methods), with the goals of uncovering the full range of existing response (which is achieving by interviewing until reaching saturation) and systematically comparing anti-racist strategies across populations. Respondents were interviewed by an African-American male or female. Interviews were transcribed and systematically coded by a team of seven trained research assistants with the help of the content-analysis software Atlas.TI. This software enables us to capture broad patterns in the data, following Miles and Huberman (1994). ${ }^{\mathrm{v}}$ These patterns add specificity to our understanding of gender and class variations based one systematically collected corpus of interviews with African-Americans.

We documented responses to stigmatization by asking interviewees about ideal or "best approach" for dealing with racism, independently of context, their responses to specific racist incidents, the lessons they teach their children about how to deal with racism, their views on the best tools their group has at its disposal to improve their 
situation, and their reactions to a list of specific strategies. This paper considers responses to probes about what respondents felt was the "best approach" to deal with racism as well as descriptions of responses to specific racist incidents. We focus on selected elements from a thematic analysis of the data.

\section{2) Experiencing Stigma: Defilement of the Self}

Respondents perceive racism to be the main problem that African-Americans confront (Hirsch and Jack, 2010). In line with the literature on racism pointing to a turn from blatant to subtle forms of racism (Kinder and Sears, 1981; Bobo and Kluegel, 1997), few said having experienced blatant racism. When probed on past encounters with racism, they also routinely referred to incidents that led them to feel a "defilement of the self” - to perceive themselves to be over-scrutinized, overlooked, underappreciated, misunderstood, and disrespected -- in short, defined negatively and/or disadvantageously (also Feagin and Sikes 1994). They convey the pain and anger associated with being excluded or treated unfairly, which contrasts with feelings associated with being inside a boundary (warmth, familiarity, intimacy, “we-ness”). These narratives of interiority (Archer, 2003), in turn, often draw on widely available cultural repertoires of morality (Hitlin and Vaisey, 2010) having to do with fairness, dignity, rights, and other similar themes, against a backdrop of heightened awareness of the pervasiveness and illegitimacy of American racism.

An African-American lawyer provides a vivid account of experiencing stigma when he describes that he found himself in an elevator with a white woman who like 
him works at the court: "She clutches her purse. I almost fainted. I almost fainted. . . . . It devastated me. But it’s happened to brothers before. Welcome to the black race, brother. You've got it. I've got it.” This lawyer interprets the woman's behavior as questioning his trustworthiness because he is black, and this, despite their similar professional status. Similarly, a recreation specialist also describes an "elevator episode" in which he finds himself alone with several white men he does not know: One [of them] made a joke about Blacks and monkeys. I said, "Man, listen, I ain't into jokes." ... His demeanor changed, my demeanor changed. All of the positive energy that was in there was being sucked out because the racial part. And the other guys, you could actually see them shrinking up in the corner because they didn't want no parts of it... [I told myself] get out of it because if I stay in it, I'm going to be in that circle and [won't be able to] get out ... The stress level rose. My tolerance was getting thin, my blood pressure peaking and my temper rising. By the grace of God, thank you Jesus, as I stepped off the elevator, there was a black minister walking past. I said, "Can I speak to you for a minute because I just encountered something that I got to talk about because I'm this far [to exploding]...." I had been at the job for a week. This is all I need to get me fired. He said, "You're a better man than me." [Now] I'm trying to get through the affair [to decide] if I was to go to the city.

Experiencing stigma has several dimensions as illustrated by the quotes below. Respondents highlight several dimensions of this experience, including being overscrutinized, misunderstood, and disrespected: 
-Over-scrutinized: Middle class and working class respondents complain that their supervisors keep a closer eye on them than on their white coworkers - for instance to make sure that they deliver their work or punch in on time. Such double-standards are perceived as both defiling and discriminatory. In one instance, a supervisor insists that Kathy, a waitress, gets rid of her braids, although she wears a net over them. She balks: "How differently would I have been treated if [my hair] was teased high?” She experiences the criticisms as an assault on her dignity because "my hair is my hair." Upon the advice of her pastor she decides to "confront" by going to the union and getting a settlement over her right to wear her hair as she wishes.

- Misunderstood: Interviewees describe episodes where their interpretation of situations clashed with those of their coworkers - as when a tall and strong African-American man jokes with his white female supervisor, while she interprets his behavior as a threat. Not having one's interpretation of reality validated and corroborated is a particularly painful aspect of stigma, as it can lead to isolation and self-doubt. One respondent explains that he often feels misunderstood at work: “[It's] all the time. I can't even say nothing in a meeting without being misunderstood ... They don't share [my] philosophy, my tastes. ... anything about me. They look at me like I got two heads." He connects these experiences to pervasive American racism without hesitation.

-Disrespected: Unfair treatment in the workplace is compounded by status hierarchies in which blacks often experience being on the lowest rungs of the ladder. For instance, describing the pecking order at her school, Betsy, a teacher explains: "You can walk 
into a teachers' room with a white male. If you say “Good morning!”, he gets the "good morning” first.” Also pointing to disrespect, an insurance salesman describes a white union employee who delays looking into formal complaints coming black workers: "She always tries to dismiss things. It's just that holier than thou, dismissive attitude, that condescending tone that they take.”

\section{3) Modalities for Responding to Stigma: Confronting and Deflating Conflict}

When probed about the "best approach” for dealing with racism (using an open-ended format), three quarters of the 110 of the African-Americans who answered this question focused on how to respond (what we call "modalities" of responses) and half of them (47 percent) favored challenging racism and discrimination. They prefer to "name the problem," “openly discuss the situation,” and "make others aware that their action makes me uncomfortable.” This compares to a third (36 percent) who prefer conflictdeflecting strategies -- believing that it is best to ignore, accept, forgive, tolerate, manage anger or walk away. ${ }^{\mathrm{vi}}$ The rest favor a mixed strategy - to "pick my battles."vii

When asked what they mean by “confronting racism,” our respondents explain that they feel compelled to speak out when something "unfair" is happening. This position is illustrated by a prison instructor. When asked how we should deal with racism he responds:

Confront it. 'Cuz people will try to tell you that it doesn't exist and it does exist [... ] Confront it. Not in a negative way, but just bring it up, discuss it. White 
folks will try to act like it doesn't exist and then they'll try to reverse it on you, to where, "You're being a racist." No, no, no!

Similarly, a city council woman explains that "the best way to deal with racism is to confront it, to sit down and have honest conversations about it. . . to learn how to coexist. I don't expect [to have] an automatic love fest. You're trying to dispel years and years and years of junk.” And for an educator, "To deal with racism, you have to open up lines of communication so that you can make it a mitigating factor ... Communication is key but [racism] needs to be dealt with.”

Confronting is also a popular strategy among our 150 respondents in responses to probes concerning how interviewees dealt with a racist incident they have been experienced in the past, with 32 percent of the responses to this question referring to confrontation (e.g., speaking out, using violence, insulting, suing, lodging a formal complain, intimidating) ${ }^{\text {viii }}$ However, 27 percent of these responses point to conflict deflation - observing, adopting strategic silence, walking away and ignoring. Smaller numbers refer to a range of other less salient responses, including the absence of reaction due to shock, surprise, or other circumstances.

Those who favor deflecting conflict as an ideal response often explain why they prefer to walk away in order to "manage their self" or their emotional energy. For instance, a talent agent does not like confronting: Racism ... you just know it's there, and decide if you want to challenge it. Nine out of ten, I don't ... Why waste my time? ... Don't spend a lot of time on the negative things. Just move on ... I used to find myself getting more frustrated trying to get even. . . to change somebody's mind. Let it go! 
A city employee has a similar perspective: "Never will I fight because of racism . .. It's just not an honorable thing ... It's not who I am, and I won't accomplish anything by it. You say what you have to say and I say what I have to say, and that's it. I don’t raise my voice, I don't argue. It's not a debate.” In many cases, deflecting conflict is explained not by a desire to "defer” but by alternative priorities: finding comfort, saving emotional energy, avoiding aggravation, anger, and violence, and focusing on professional and other goals. Others "manage the self" to avoid confirming stereotypes about “angry blacks.” Yet other “conflict deflectors” want to avoid confrontation because they do not trust non-blacks or are pessimistic about improving the situation. Mixing explanations, a teacher for instance states plainly: "Why waste my time; I just don't give them the chance to make me angry.”

\section{4) Tools for Gaining Recognition: Education and the Management of the Self}

When questioned about "the best way to respond to racism," two third of our interviewees ( 65 percent) focused not on modality but on what they consider the "best tools” which include religion; integration; “dressing up” (one respondent mentioned wearing Gucci when shopping to avoid police profiling); sarcasm and joking to prevent escalation; and "getting used to it." For a third of them (37 percent), the best tool is "teaching the ignorant," this being the most popular strategies. ${ }^{\text {ix }}$ Below we examine this anti-racist tool, along with "managing the self." While the first one concerns primarily with managing perception or the external self (or social categorization), the second one is also oriented toward the management of the internal self (including self identification; see Jenkins, 1996; Cornell and Hartman, 1999).

\section{A) "Teaching the Ignorant"}


Interviews are replete with statements about the need to educate non-blacks about African-Americans and their culture and history. Respondents believe they can gain recognition by challenging stereotypes and diffusing a more complex and detailed portrait of Black people. This is illustrated by a female minister who believes that racism is passed on from generation to generation. She emphasized the importance of taking time to explain the history of blacks to other Americans so that they can move beyond a "majority/minority framework.” Expressing her desire for greater social inclusion, she states that she would like to "Stomp [racism] in the ground . . . we really need to stop the "them/us" mentality and develop a 'we' mentality, [explain] that the race is human.”

African-American respondents are particularly aggravated by white ignorance about blacks. Turning a familiar stereotype about African-Americans on its head, one explains: "I feel sorry for you. Pick up a book and read. Understand my history as well as I understand yours.” Suburban whites are often singled out for their ignorance and for being out of touch and isolated from the "real world.” For instance, one insurance salesman says of someone who grew up in the white suburb of Westfield: "You really need to go out here and experience life. Get out the four walls that you're accustomed to and go outside that box and deal with people in a different light." Lack of awareness of class diversity among Blacks is a particular concern (also Lacy 2007). As an entrepreneur puts it, speaking about whites:

[They think] there are some good blacks and there's bad blacks. "You're one of the good ones, Darren." I've even had people interview me, “Is there anyone else kind of like yourself?" What does that mean? I got a thousand people like 
me. All of my friends are like me. We've all been to college. We all drive nice cars if we've been working and got a little money.

Respondents tell us that teaching non-Blacks about Blacks is a daunting challenge, and not one that should not be pursued at any price: it has to be balanced against other considerations, including that of "managing the self."

\section{B) Managing the Self}

While "informal teaching" aims to challenge how the out-group views the ingroup, the management of the self has to do with 1) projecting an image of oneself that is positive or conform to out-group norms, so as to gain recognition; 2) self-protection and the development of various aspects of identity. ${ }^{\mathrm{x}}$

Our respondents explain that managing the self is essential in order to avoid confirming racial stereotypes or being perceived as incarnating them - stereotypes like that of the "angry blacks" for instance. This is a challenge because stigmatization often triggers indignation. An educator who works in a white environment explains how he changed in response to feedback he received:

I was told "We're looking for someone who is not confrontational ... Our family backgrounds, similar upbringings, mean we deal from that viewpoint.”. . . I'm modifying my behavior. I'm Bo-Jangling and tap dancing, more smiling. . . You want to be liked, so that you'll debunk the stereotype that they inevitably have of you being hostile... You smile, because, you find yourself not having the economic roots to be in a position to say, "You know what, I don't need this, 
and I can be free to say what I want” ... You say, "OK, well, I'll keep that in mind. I won't send any more [angry] emails.

Similarly, many describe having to learn to contain emotions (especially in response to feelings of injustice) and maintain control ("thinking about my upbringing," "not being a jerk") in work settings. One explains the need to contain his anger when a waitress attended to whites who walked in a restaurant after him: "I said [to myself]: diffuse this because I don't want to go to where she's at, because it would get out of control. . . I'm not going to make an idiot out of myself, but I make sure that I'm treated fairly.” Similarly, upon learning that one of his coworkers thought he was not qualified for a job, a technician explains that he resisted getting angry and instead "tried] to learn these lessons. Instead of reacting, I like to do my own thing. I talked to some people [to figure out how to get promoted].” The opposite response is exemplified by an AfricanAmerican construction worker who was the only person to be written up because he did not wear the standard hat: "I exploded. Honestly, yes, I exploded. There was a lot of foul language being used and things of that nature. Nothing as far as physical violence though.”

Against a background of pervasive racism, some believe it is essential to "manage the self” in all interactions with non-blacks whom they don't trust. This is to avoid being “trampled over.” In the words of an insurance salesman, this requires vigilance: “[At work] if you show a sign of weakness, they are going to keep on doing "it.” When you're strong and you exude that confidence, it's hard for them ... They look for you to be unsure of yourself.” 
The management of the self may also require pragmatic "role distance:” dealing with each situation without investing one's ego, as explained by a managing partner in a law firm who describes how his white clients turn to his white subordinates for solutions, instead of to him:

The bodies shift, the questions. Hey. I'm not here to change their minds, to disagree with them, give them a social agenda, or try to bring them to a certain level of consciousness.[I think] "What I need you to do is agree with whatever they say. And let them know that you're going to have your guy work on [it]. And I'm going to be your guy, for this meeting." Because he's going to feel more comfortable, knowing this.

The professional role of this manager gives him a way out through competence and service delivery. But it is not without a cost: “There are so many [instances], I look at [my clients] and [feel like saying], “Listen, how dare you?” For people like me, who are in finance or something like that, numbers are numbers. You can hide behind them as long as people don't see you. When they see you, it's like, "Was it you I was trusting?” Such management of self requires a great deal of self-control and is an added source of stress that contributes to racial disparities in health (Williams, Neighbors, and Jackson, 2008).

"Managing the self” may also mean performing emotional work aimed at making professional identity more salient than racial identity at work. This effort can also be taxing, as described by an entertainer:

There have been times in my past employment, when you're working together with people [of different race]. I always try to make them understand . . It's not 
all about race all the time. It's about working together no matter who you are. That's where I'm at ... In the 60s, it was a little different, everything was "Black Power!" That was the time for it.

This interviewee exemplifies that "managing the self" can be spurred by motivations other than a need for destigmatization. It can also be driven by a desire to develop working relationships with a range of people. Lamont, Fleming and Welburn (2011a) explore other motivations described by respondents such as a wish to construct an identity that is not primarily defined by race, a concern with the preservation of energy and psychological resources through lowering stress and refusing to be baited, and a will to enjoy the rewards of professional success while forgetting racial struggles.

\section{5) Conclusion}

This paper moves beyond the social psychological literature on coping with racism and the sociological literature on responses to racism by documenting the relative salience of modalities and tools for responding to stigmatization, with a focus on "best approaches." We found that African-Americans are somewhat more likely to favor "confronting" racism over "deflating conflicts" as a modality for responding to racism, and that "teaching the ignorant" is the most valued tool. We found that deflating conflict is often motivated by a concern for "managing the self” which takes a range of meanings.

A better understanding of the daily management of inter- and intra-group relations is essential if we are to fully comprehend the mechanisms behind the making and unmaking of group boundaries (Todd, 2004; Lamont and Bail, 2005; Wimmer, 2008). One cannot understand the process of ethnoracial identity formation without 
considering the dialogue members of stigmatized groups carry out (privately or publicly) with the dominant meanings associated with their group. Responses to stigma can weaken symbolic boundaries between groups (by downplaying differences), but they may also result in their greater rigidity (when group membership is affirmed and defined in opposition to that of out-groups). This in turn can affect social boundaries (residential segregation, intermarriage, and access to a range of resources).

Responses to stigmatization are enabled by the cultural repertoires provided to African-Americans as well as by their remote and proximate circumstances (Lamont, 2000). Indeed, Lamont, et al, 2011a) show how responses are fed by collective myths and memories about national identity (including the American dream and the civil rights movements); by repertoires about matrixes of human worth favored by neo-liberalism that emphasize competition, consumption, individualization, and personal achievement; and by repertoires tied to the shared history and identity of the African-Americans as resilient and moral people. How the individual defines the situation - what $\mathrm{s} /$ he thinks is possible or doable in specific situation - and what s/he values also shapes how s/he “cope” (Folkman and Moskowitz, 2004).

Many questions remain - unanswered questions that can be systematically addressed with our data (see Lamont et al, 2001b): Are women more likely to confront racism than men, given that black men are more readily associated with violence and aggression? Are working class individuals less likely to confront than middle class individuals, given their greater vulnerability in the labor market? How do responses to racism vary with past experiences with discrimination? Are more experienced individuals more prone to "manage the self" and avoid costly direct confrontation? 
Whereas Hochschild (1979) connects emotion rules to institutions and mode of production, we also need to explore more closely the impact of contexts on responses, including definitions of the situation, and compare our results with the literature. For instance, how are responses affected by the nature of incident (e.g., assault on dignity, discrimination in the workplace, violence), the context in which it occurs (at work, in restaurants, in search for employment or housing, while interacting with police officers, etc.), and whether individuals live in predominantly white, black or mixed environments. Finally, more conceptual work is needed to make explicit how a cultural sociology approach to responses to stigmatization differs from and complements social psychological approaches to coping.

Experiencing stigmatization has been shown to cause feelings of worthlessness that affects health and well-being (Williams, Neighbors and Jackson, 2008). However, social scientists have not fully considered how responses to these experiences can moderate this impact—shaping how the "wear and tear" of inequality gets under the skin and become "embodied" (Hertzman and Boyce 2010). This question will motivate our future agenda (see Hall and Lamont, 2009).

\footnotetext{
i Inspired by Essed (1991), we define "everyday antiracism” as the rhetoric and strategic resources deployed by individual members of stigmatized groups to rebut the notion of their inferiority in the course of their daily life (also Lamont and Fleming, 2005). This expands on Aptheker's (1992) definition of antiracism as rhetoric aimed at disproving racial inferiority. Studies on white anti-racism have developed rapidly in recent years (O’Brien 2007; Warren 2010), unlike studies of black anti-racism, which mostly pertains to the black middle class.

${ }^{\text {ii }}$ Feagin (1991; also Feagin and Sikes 1994) concerns accounts of racism in public places by middle class African-Americans. He provides evidence pertaining to emotional responses (especially anger) but does not examine the management of emotions (and the self) in a sustained way. The main argument is that blacks no longer simply 'defer' to whites and have coping strategies that range from confrontation to withdrawal. This research does not document the full range of responses, their
} 
frequency or salience, and ideal responses. Moreover, it does not examine in detail intermediate strategies such as accommodation in which blacks' contain/manage their emotions and/or their appearance in order to respond to and/or avoid racism. iii While the first group is composed of college-educated entrepreneurs, professionals, and managers (with at least a 2-year degree), the second group is composed of high school graduates or General education degree (GED) holders with stable employment as blue-collar workers or low-status white-collar workers.

${ }^{\text {iv }}$ Logan and Deane (2003) compare African-Americans living in the New York area and their national counterpart.

${ }^{v}$ We do not claim that our data is nationally representative.

${ }^{v i}$ Conflict-deflators may underreport their responses compared to confronters. We consider narratives of responses - what respondents believe and remember -- and not responses themselves.

vii Space constraints prevent a discussion of mixed strategies adopters.

viii We coded 642 responses to this question. Respondents were free to mention as many instances as they wish.

${ }^{\text {ix }}$ Other tools were mentioned by only a few respondents and thus not reported here. x Goffman (1959) on "presentation of self" is crucial to analyze how African-Americans manage stigma. Picca and Feagin (2007) and Eliasoph (1999) wrote about front stage and backstage performance among whites in interracial relationships, but treatments of the management of self among black are few. 


\section{REFERENCES}

ANDERSON, ELIJAH 1999 Code of the Street. Decency, Violence, and the Moral Life of the Inner City, New York: W.W. Norton

APTHEKER, HERBERT 1992 Anti-Racism in U.S. History: The First Two Hundred Years, Westport, CT: Greenwood Press

ARCHER, MARGARET 2003 Structure, Agency and the Internal Conversation, New York: Cambridge University Press

BANKS, PATRICIA A. 2009 Represent: Art and Identity Among the Black UpperMiddle Class, New York: Routledge BOBO, LAWRENCE et al. 1997 'Laissez-faire Racism: The Crystallization of a Kinder, Gentler, Anti-Black Idology', in Steven Tuch and Jack Martin (eds) Racial Attitudes in the 1990s: Continuity and Change. Westport, CT: Praeger

CLARK, RODNEY et al. 1999 'Racism as a Stressor for African Americans: A Biopsychosocial Model', American Psychologist, vol. 54, no. 10, pp. 805-816

CORNELL, STEPHEN and HARTMAN, DOUGLAS 1997 Ethnicity and Race. Making Identity in a Changing World, Thousand Oaks, CA: Pine Forge Press CROCKER, JENNIFER et al. 1998 'Social Stigma', in Susan Fiske et al. (eds) Handbook of Social Psychology, Boston: McGraw-Hill ESSED, PHILOMENA 1991 Understanding Everyday Racism: An Interdisciplinary Theory, London: Sage Publications

ELIASOPH, NINA 1999 'Everyday Racism” in a Culture of Political Avoidance: Civil 
Society, Speech, and Taboo', Social Problems, vol. 46, no. 4, pp. 479-499

FEAGIN, JOE R. 1991 ‘The Continuing Significance of Race: Antiblack

Discrimination in Public Places’ American Sociological Review, vol. 56, pp. 101-116

FEAGIN, JOSEPH and SIKES, MELVIN 1994 Living with Racism: The Black Middle

Class Experience, Boston, MA: Beacon

FOLKMAN, SUSAN. \& MOSKOWITZ, JUDITH T. 2004 'Coping: Pitfalls and

Promise’ Annual Review of Psychology, vol. 55, pp. 745-774

FREDERICK, MARLA F. 2003 Between Sundays: Black Women and Everyday

Struggles of Faith, Berkeley, CA: University of California Press

GOFFMAN, ERVING 1959 The Presentation of Self in Everyday Life, New York, NY:

Doubleday

--- 1963 Stigma, Englewood Cliffs, NJ: Prentice Hall

HALL, PETER A. \& LAMONT, MICHÈLE 2009 Successful Societies: How

Institutions and Culture Matter for Health, New York: Cambridge University Press

HARRIS-LACEWELL, MELISSA 2004 Barbershops, Bibles, and BET: Everyday Talk

and Black Political Thought, Princeton: Princeton University Press

HERTZMAN, CLYDE and BOYCE, TOM 2010 'How Experience Gets Under the Skin to Create Gradients in Developmental Health', Annual Review of Public Health, vol. 31, pp. 329-347

HIRSCH, NICOLE and JACK, ANTHONY 2010 'What We Face: Framing Problems in the Black Community', Paper presented at the conference on "Responses to Discrimation and Racism: Comparative Perspectives", Cambridge, MA: Center for European Studies, Harvard University 
HITLIN, STEVEN and VAISEY, STEPHEN (ed) 2010 Handbook of Sociology of Morality, New York, NY: Springer

HOCHSCHILD, ARLIE 1979 'Emotion Work, Feeling Rules, and Social Structure', American Journal of Sociology, vol. 85, no. 3, pp. 551-575

JENKINS, RICHARD 1996 Social Identi,. London: Routledge

KINDER, DONALD and SEARS, DAVID O. 1981 'Prejudice and Politics: Symbolic

Racism versus Racial Threats to the Good Life', Journal of Personality and Social

Psychology, vol. 40, no. 3, pp. 414-431

LACY, KARYN. R. 2007 Blue-Chip Black: Race, Class, and Status in the New Black Middle Class, Berkeley: University of California Press

LAMONT, MICHÈLE 2000 The Dignity of Working Men: Morality and the Boundaries of Race, Class, and Immigration. Cambridge: Harvard University Press.

--- 2009 'Responses to Racism, Health, and Social Inclusion as a Dimension of Successful Societies', in Peter A. Hall And Michèle Lamont (eds) Successful Societies: How Institutions and Culture Matter for Health, New York: Cambridge University Press

LAMONT, MICHÈLE and AKSARTOVA, SADA 2002 'Ordinary Cosmopolitanisms: Strategies for Bridging Boundaries among Working Class Men', Theory and Society, vol. 19, no. 4, pp. 1-15

LAMONT, MICHÈLE and BAIL, CHRISTOPHER 2005 'Sur les frontières de la rconnaissance. Les catégories internes et externes de l'identité collective', Revue Europenne des Migrations Internationales, vol. 21, no. 2, pp. 61-90 LAMONT, MICHÈLE and FLEMING, CRYSTAL 2005 'Everyday Anti-Racism: 
Competence and Religion in the Cultural Repertoire of the African-American Elite and Working Class', The Du Bois Review, vol. 2, no. 1, pp. 29-43

LAMONT, MICHÈLE et al. 2011a 'Responses to Discrimination and Social Resilience Under Neo-Liberalism: The Cases of Brazil, Israel, and the United States’. Prepared for Social Resilience in the Age of Neo-Liberalism. Peter Hall And Michèle Lamont (eds)

LAMONT, MICHÈLE et al. 2011b 'Variations in African-American Responses to Stigmatization: Contexts and other Determinants.' Prepared for Responses to Stigmatization: Brazil, Israel and the United States, Michèle Lamont (ed.) LAMONT, MICHÈLE and MOLNÁR, VIRÀG 2002 'How Blacks Use Consumption to Shape Their Collective Identity: Evidence from African-American Marketing Specialists’, Journal of Consumer Culture, vol 1, no. 1, pp. 31-45

LAMONT, MICHÈLE and MORNING, ANN and MOONEY, MARGARITA 2002 'North African Immigrants Respond to French Racism: Demonstrating Equivalence through Universalism', Ethnic and Racial Studies, vol. 25, no. 3, pp. 390-414 LINK, BRUCE G. and PHELAN, JO 2000 'Evaluating the Fundamental Cause Explanation for Social Disparities in Health', Handbook of Medical Sociology, pp. 3346

LOGAN, JOHN R. and DEANE, GLENN 2003 'Black Diversity in Metropolitan America'. Albany: Lewis Mumford Center for Comparative Urban and Regional Research, SUNY Albany MCADAM, DOUG 1988 Freedom Summer, Oxford: Oxford University Press 
MILES, MATTHE B. and HUBERMAN, MICHAEL 1994 Qualitative Data Analysis: An Expanded Sourcebook, Thousand Oaks, CA: Sage Publications MORNING, ANN 2009 'Toward a Sociology of Racial Conceptualization for the 21st Century', Social Forces, vol. 87, no. 3, pp. 1167-1192

O'BRIEN, EILEEN 2007 'Antiracism', in Hernán Vera And Joe R. Feagin (eds) Handbook of the Sociology of Racial and Ethnic Relations, New York: Springer OYSERMAN, DAPHNA et al. 2002 'Rethinking the Individualism and Collectivism: Evaluation of Theoretical Assumptions and Meta-Analyses', Psychological Bulletin, vol. 128, pp. 3-73

OYSERMAN, DAPHNA \& SWIM, JANET K. 2001‘Social Stigma: An Insider’s View’, Journal of Social Issues, vol 57, no. 1, pp. 1-14

PATTILLO-MCCOY, MARY 1999 Black Picket Fences. Privilege and Peril among the Black Middle Class, Chicago, IL: University of Chicago Press

PICCA, LESLIE and FEAGIN, JOE R. 2007 Two-faced Racism: White in the Backstage and Frontstage, New York, NY: Routledge

PINEL, ELIZABETH C. 1999 'Stigma Consciousness: The Psychological Legacy of Social Stereotypes', Journal of Personality and Social Psychology, vol. 76, no. 1, pp. $114-128$

TAJFEL, HENRI and TURNER, J.C. 1979 'An Integrative Theory of Intergroup Conflict', in Mary Joe Hatch And Majken Schultz (eds) Organization Identity: A Reader, Oxford: Oxford University Press TODD, JENNIFER 2004 'Social Transformation, Collective Categories and Identity Change', Theory and Society, vol. 34, no. 4, pp. 429-463 
WARIKOO, NATASHA and CARTER, PRUDENCE 2009 'Cultural Explanations for Racial and Ethnic Stratification in Academic Achievement: A Call for a New and Improved Theory', Review of Educational Research, vol. 79, no. 1, pp. 366-394 WARREN, MARK 2010 Fire in the Heart: How White Activists Embrace Racial Justice, New York, NY: Oxford University Press

WILLIAMS, DAVID R. and et al. 2008 'Racial/Ethnic Discrimination and Health: Findings from Community Studies', American Journal of Public Health, vol. 98, no. 1, pp. S29-S37

WIMMER, ANDREAS 2008 'The Making and Unmaking of Ethnic Boundaries: A Multi-level Process Theory', American Journal of Sociology, vol. 113, no. 4, pp. 9701022

YOUNG, ALFORD A., JR. 2004 The Minds of Marginalized Black Men: Making Sense of Mobility, Opportunity, and Future Life Chances, Princeton, NJ: Princeton University Press 
Acknowledgement

This research was suppoerted by the National Science Foundation (grant \# SES-

0701542).We thank Steven K. Brown for his assistance with statistical analysis and Travis Clough for his technical assistance. This paper has benefitted from comments from Stanley Bailey, Christopher Bail, Karyn Lacy, Nissim Mizrachi, Hilary Silver, David Williams, Andreas Wimmer, and two anonymous reviewers. 
CRYSTAL FLEMING is a Ph.D candidate in Sociology at Harvard University.

ADDRESS: Department of Sociology, Harvard University, 33 Kirkland St., Cambridge, MA. Email: Cfleming@fas.harvard.edu.

MICHELE LAMONT is Robert Goldman Professor of European Studies and Professor of Sociology and African and African-American Studies at Harvard University

ADDRESS: Department of Sociology, Harvard University, 33 Kirkland St., Cambridge, MA.Email: mlamont@wjh.harvard.edu.

JESSICA S. WELBURN is a Doctoral Candidate in the Department of Sociology and a Doctoral Fellow in the Multidisciplinary Program in Inequality and Social Policy at Harvard University.

ADDRESS: Department of Sociology, 509 William James Hall, 33 Kirkland St., Cambridge, MA, 02138. Email: jwelburn@fas.harvard.edu 